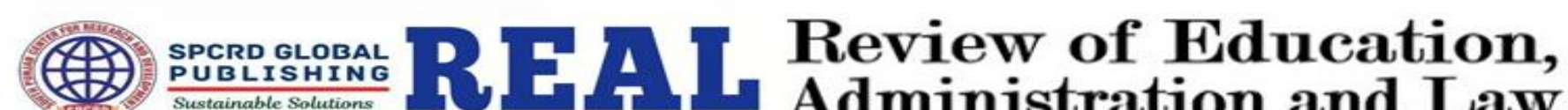 \\ Journal homepage: http://real.spcrd.org ISSN (Print): 2708-1788 ISSN (Online): 2708-3667
}

\section{The Effect of Mergers and Acquisitions on the Financial Performance of Micro Finance Banks}

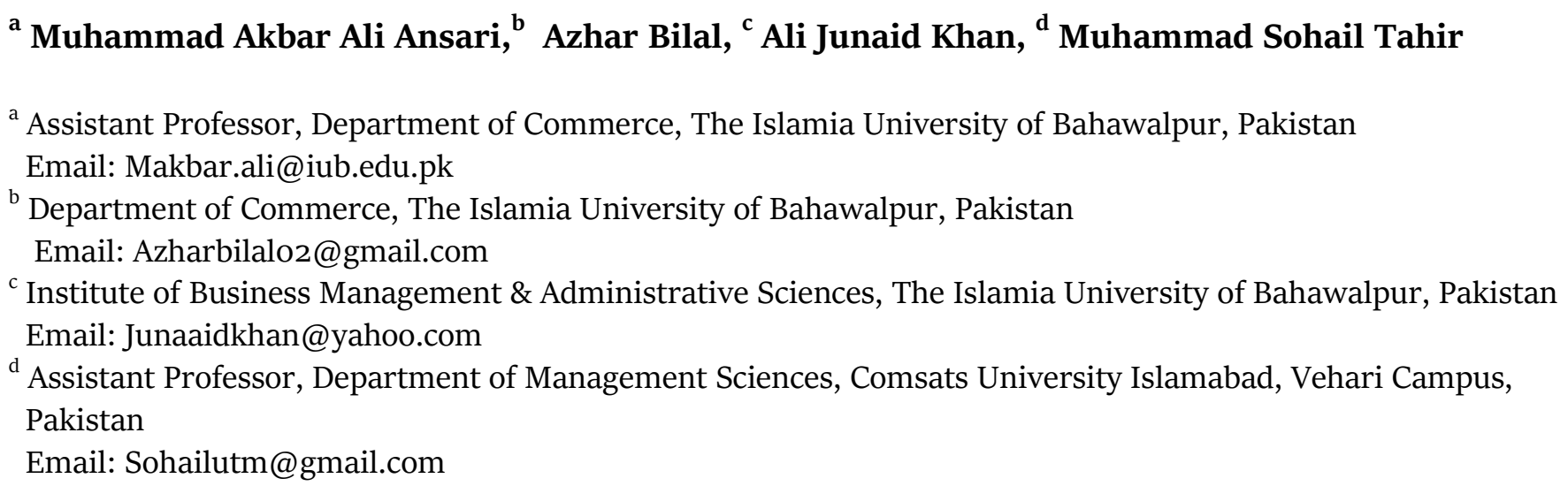

\begin{tabular}{l}
\hline ARTICLE DETAILS \\
\hline History: \\
Accepted 16 December 2021 \\
Available Online December 2021
\end{tabular}

\section{Keywords:}

Financial Performance, Mergers and Acquisition and Microfinance Banks

JEL Classification: F36, F39, G21

DOI: $10.47067 /$ real.v4i4.202

\section{ABSTRACT}

The basic purpose of this study to examine effect of mergers \& acquisitions on the financial performance of Pakistan's micro finance banks. Financial institutions must change their business strategies as a result of rapid technological advancements because they play such an important part in any country's economy. Several national and international studies on mergers and acquisition banking have been conducted to investigate the various elements. In this study, 13 financial ratios were calculated, which shows that there is no significant effect of mergers \& acquisitions on the financial performance of microfinance banks in Pakistan. There are indicators that measured through financial ratios and the comparison is made using a paired T-test. Three years of data, two years before and one year after mergers \& acquisitions, are taken as a sample. Out of 13 ratios, 11 ratios are examined: Investment to Total Assets (ITA), Deposit to Total Assets (DTA), Return on Assets (ROA), Earnings per Share (EPS), and Net Profit Margin (NPM).

(C) 2021 The authors. Published by SPCRD Global Publishing. This is an open access article under the Creative Commons AttributionNonCommercial 4.0

Corresponding author's email address: Junaaidkhan@yahoo.com

\section{Introduction}

Financial institutions must change their business strategies as a result of rapid technological advancements because they play such an important part in any country's economy. Bank financial performance financial institutions must change their business strategies as a result of rapid technological advancements because they play such an important part in any country's economy. Several national and international studies on mergers and acquisition banking have been conducted to investigate the various elements. In this study, 13 financial ratios were calculated. The indicators are 
measured through financial ratios and the comparison is made using a paired T-test. Three years of data, two years before and one year after mergers \& acquisitions, are taken as a sample. According to Ongore and Kusa (2013), 11 ratios, including Investment to Total Assets (ITA), Deposit to Total Assets (DTA), Return on Assets (ROA), Earnings Per Share (ROCE), and Net Profit Margin (NPM), are examined. According to Ongore and Kusa (2013), these are important to any country's economic success. When financial performance is good, more investment is made, resulting in financial growth, whereas poor financial performance results in bank failures and a negative influence on economic growth. The banking sector is now playing an important role in the country's economic growth, providing funds for industrialization and resource utilization.

Financial performance in financial institutions, according to Stoner (2003), refers to the ability to function efficiently, profitably, survive, grow, and respond to environmental opportunities and risks. Various studies found that performance is judged by how well the company uses resources to achieve its goals (Khan \& Iqbal, 2020, Khan, Tufail \& Ali, 2021). It provides a variety of services, like deposits, loans, and the provision of new services in a timely manner, as well as creating jobs and economic progress in the country. Capital, bank deposits, pay loans, and personnel are only a few of the internal and external factors that affect a bank's financial performance. There are several specific elements that influence financial performance, such as capital sufficiency, management efficiency, asset quality, and management liquidity, as well as macroeconomic aspects like inflation, interest rates, political uncertainty, and gross domestic product.

Different authors defined the term "microfinance" differently. "Microfinance is a development tool that provides or grants financial services such as savings, very small credits, micro insurance, micro-leasing, and money transfers to help the extremely poor in establishing or expanding their businesses as defined by Negehnue and Nimbo (2010)." Microfinance institutions, like conventional banking, play a critical part in any country's growth. According to "Agarwal and Sinha" (2010), the basic purpose of the institutes of microfinance is to alleviate poverty, which is why the government, corporate leaders, academics are all interested in microfinance. Many participants have been drawn into microfinance programs particularly banks that established microfinance branches because they saw it as a good source of deposit and low-risk mass lending.

Microfinance's demand is growing all the time, but it's also dealing with a slew of issues, including operational and financial sustainability, which has a negative impact on its financial performance. Microfinance banks' financial performance, like that of commercial banks, is influenced by a number of factors. With all of the elements that affect the financial performance of general banking and microfinance banking, merger and acquisition (mergers and acquisition) is another factor that has an impact on bank financial performance. The institution used the most effective and well-known strategy in this situation, which is merger and acquisition (mergers and acquisition). Mergers are when two or more companies merge into one, whereas acquisitions are when one company completely buys out another, clearly identifies itself as the new owner, and dissolves the old one.

According to Shakoor et al. (2014), mergers \& acquisitions in Pakistan's banking sector began in 2002. After the mergers and acquisition banking sector completed its transformation, it has become a more competitive and profitable industry, but bank performance has not improved much. Kayani et al. (2013) examine whether a well-established banking sector is the backbone of any country's economic stability. It investigates the effect of mergers and acquisition on shareholder wealth and financial performance of banks. The findings reveal that after mergers \& acquisitions, shareholder wealth and performance of bank performance decline, which is not helpful in Pakistan. 
However, mergers \& acquisitions in microfinance banks are a relatively new phenomenon in Pakistan. Telenor Pakistan purchased a 51 percent stake in Tameer Bank in 2009.Microfinance banks play a critical role in every country's economic development. However, minimal attention is paid to the impact of microfinance bank mergers \& acquisitions, particularly in Pakistan.

According to data from Pakistan's Competition Commission, over 426 mergers \& acquisitions took place between 2005 and December 31, 2021. However, the phenomenon of mergers \& acquisitions in microfinance banks is relatively new in Pakistan and has received little attention. The purpose of this study is to examine the effects of mergers \& acquisitions on the financial performance of Pakistan's microfinance institutions, which are relatively new and understudied.

\section{Literature Review}

Various studies have been conducted on the financial performance of banks after mergers \& acquisitions, as well as on the financial performance of microfinance organization worldwide. However, there has been no study on microfinance bank mergers \& acquisitions in Pakistan to far. As a consequence, this thesis contributes to the existing body of knowledge. The following is a review of the literature:

\subsection{Financial Performance}

A strong banking industry is critical for every country's economic success as well as its ability to absorb losses. Asset management, operational efficiency, and institution size are three types of indicators used to quantify the financial performance of financial institutions, according to Tarawneh (2006), to assess a bank's financial performance, the relationship between return on assets, asset management operational efficiency, and the size of the bank is assessed. Gupta et al, (2021) explore the effects of mergers \& acquisitions on the financial performance of the construction and real estate sector using a wide range of financial ratios. Aggarwal (2019) the merger had a considerable significant effect on the acquiring firm's profitability and liquidity over a five-year period but had no meaningful effect on the company's solvency status. Shah and Jan (2013) investigate that the financial system plays an important role in the stability and economic growth and provides resources to multiples industries of Pakistan. The top 10 commercial banks in Pakistan were employed as a sample size, and correlation and regression methods were used to determine the institutions' financial performance. Economic growth in a developed financial system is achieved by saving and putting that money to productive use.

\subsection{Microfinance Institutions}

Microfinance institutes (MFIs), like traditional banks, play an important role in a country's stability and progress. According to Kipesha (2013), MFIs want to give financial services to impoverished people in order to alleviate poverty. So, in order to attain this goal, microfinance institutions must better organize their resources and operate in an appropriate location. Five balance scored parameters defined by MFC (2007) are used to measure the financial performance of MFIs, using 29 MFIs operating in Tanzania as a sample size. Bi and Pandey (2011) investigated the performance of commercial banks and microfinance institutes in India, finding that microfinance institutes incur high costs due to their doorstep delivery, however, that these high costs are related with employee training and short-term borrowing.

\subsection{Mergers \& acquisitions}

According to Fatima and Shahzad (2014), a merger happens when two or more businesses combine into one, while an acquisition occurs when one business acquires another and re brands itself as the new owner while simultaneously dissolving the prior one. 
The first moving ridge of mergers took place between 1897 and 1904, and it was characterized by horizontal mergers and organization. The second stage of the merger began in 1916 and ended in 1929, and it was likewise a horizontal merger. The third period of merging began in 1965 and lasted until 1969; it was conglomerate in form and backed by owner capital. From 1981 to 1989, the fourth wave of mergers occurred, which was greater than the third wave and included anti-absorption legislation. The fifth wave of mergers began in 1992 and ended in 2000, with the majority of mergers occurring in the telecom and banking sectors, with most of them being supported by capital rather than debt (Fatima and Shahzad, 2014).

According to Malik et al. (2014), most firms employ mergers and acquisition as a strategic strategy for organization restructuring. Initially, this movement was limited to wealthy countries such as the United States and the United Kingdom. However, developing countries began to employ the mergers and acquisition approach. According to Kayani et al. (2013), the banking sector in Pakistan is well-established and plays an important role in the economy. mergers \& acquisitions are not a typical occurrence in Pakistan, hence the volume of mergers and acquisition transactions is minimal. However, in the banking sector, various transactions have occurred through mergers \& acquisitions.

Shakoor et al. (2014) investigate if mergers \& acquisitions affect the financial performance of banks. For the past two to three decades, mergers \& acquisitions have been utilized as a strategic tool to improve efficiency and effectiveness. Developed countries, such as the United Kingdom and the United States, have more merger and acquisition instances than developing countries. However, most firms in developing nations are already using the mergers and acquisition strategy. The first mergers and acquisition cases in Pakistan occurred in 2002. Financial ratios for profitability, solvency, and liquidity are used to evaluate financial performance.

After reading a number of publications, it becomes clear that much research has been done on financial performance, microfinance institutions, and mergers \& acquisitions in various industries. However, in Pakistan, the phenomenon of microfinance bank mergers \& acquisitions is new and understudied. Microfinance plays a critical role in every country's economic progress. However, minimal attention is paid to the impact of microfinance bank mergers \& acquisitions, particularly in Pakistan. As a result, the influence of mergers \& acquisitions on the financial performance of microfinance banks in Pakistan will be investigated in this study.

\section{Conceptual framework}

Shakoor et al. (2014) examine whether mergers \& acquisitions have an influence on bank performance by analyzing the effects of mergers \& acquisitions on the financial performance of Pakistani banks using ratio analysis. The findings indicate that mergers \& acquisitions have a detrimental effect on the financial performance of Pakistani banks. Abbas et al. (2014) evaluate the financial performance of banks in Pakistan before and after mergers \& acquisitions using financial parameters. The findings indicate that there is little variation in bank performance before and after mergers \& acquisitions. 


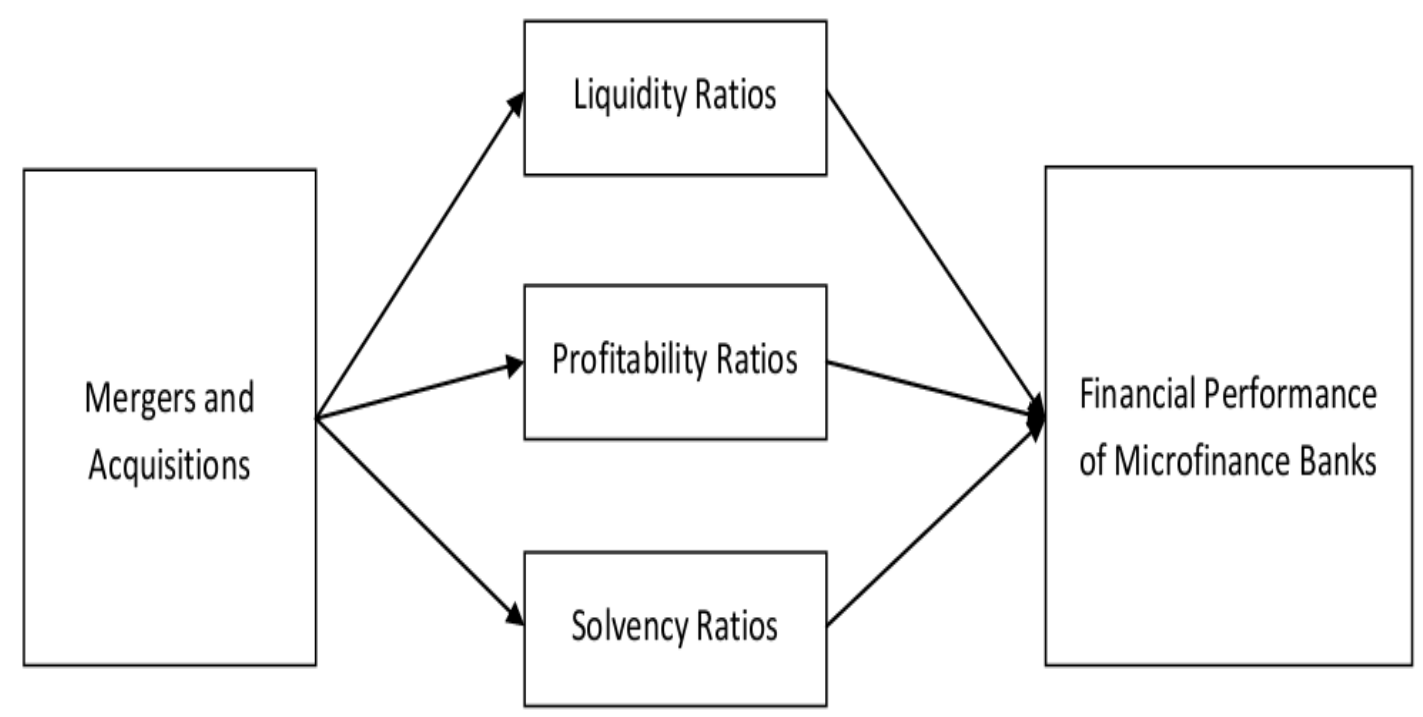

The following Ratios are measure:

1. In Liquidity Ratios, measured the Deposit to Total Assets Ratio, Current Ratio, Advances to Total Assets Ratio and Current Ratio.

2. Profitability Ratios, measured the Return on Capital Employed Ratio, Return on Assets, Return on Equity, Earnings per Share Ratio and Net Profit Margin.

3. Solvency Ratios, measured the Interest Coverage Ratio, Debt Ratio, Capital Ratio and Debt to Equity Ratio.

\section{Description of Variables}

Table. 1

\begin{tabular}{|c|c|c|c|c|}
\hline r. & \multicolumn{2}{|c|}{ Variables } & Calculation & References \\
\hline & Current Ratio & $\mathrm{R}$ & $\begin{array}{l}\text { Current Assets / } \\
\text { Current Liabilities }\end{array}$ & $\begin{array}{l}\text { "(Kumara } 8 \\
\text { Satyanarayana, } 2013 \text { and Ray, } \\
\text { 2013)" }\end{array}$ \\
\hline & $\begin{array}{l}\text { Investment to } \\
\text { Total Assets }\end{array}$ & TA & $\begin{array}{l}\text { (Total Investment / } \\
\text { Total Assets) * } 100\end{array}$ & $\begin{array}{l}\text { "(Ahmed and Ahmed, } \\
\text { 2014; Arshad, 2012; Alam et al. } \\
2011 \text { and Abbas et al. 2014)" }\end{array}$ \\
\hline & $\begin{array}{l}\text { Deposit to Total } \\
\text { Assets }\end{array}$ & TA & $\begin{array}{l}\text { (Deposit / Total Assets) } \\
{ }^{*} 100\end{array}$ & $\begin{array}{l}\text { "(Ahmed and Ahmed, } \\
2014 \text { and Shakoor et al. 2014)" }\end{array}$ \\
\hline & $\begin{array}{l}\text { Advances to Total } \\
\text { Assets }\end{array}$ & TA & $\begin{array}{l}\text { (Advances / Total } \\
\text { Assets) * } 100\end{array}$ & $\begin{array}{l}\text { "(Ahmed and Ahmed, } \\
\text { 2014; Abbas et al. 2014; Arshad, } \\
\text { 2012; Alam et al. 2011)" }\end{array}$ \\
\hline & Return on Assets & ROA & $\begin{array}{l}\text { (Net Profit after Tax / } \\
\text { Total Assets) }{ }^{*} 100\end{array}$ & $\begin{array}{l}\text { "(Arshad, 2012; Allah- } \\
\text { Yar, 2012; Kumara and } \\
\text { Satyanarayana, 2013; Ilahi et al. } \\
\text { 2014; Alam et al. 2011; Abbas et } \\
\text { al. 20114; Shakoor et al. 2014; } \\
\text { Ahmed and Ahmed, 2014; } \\
\text { Kemal, 2011)" }\end{array}$ \\
\hline
\end{tabular}




\begin{tabular}{|c|c|c|c|c|}
\hline & Return on Equity & ROE & $\begin{array}{l}\text { (Net Profit after Tax / } \\
\text { Total Equity) * } 100\end{array}$ & $\begin{array}{l}\text { “( Ray, 2013; Abbas et al. } \\
\text { 2014; Alam et al. 2011; Arshad } \\
\text { 2012; Ilahi et al. 2014; hakoor et } \\
\text { al. 2014; Ahmed \& Ahmed, 2014; } \\
\text { Kemal, 2011)" }\end{array}$ \\
\hline & $\begin{array}{l}\text { Net Profit } \\
\text { Margin }\end{array}$ & NFM & $\begin{array}{l}\text { Net Profit before Tax / } \\
\text { Net Sales)* } 100\end{array}$ & $\begin{array}{l}\text { "(Kayani et al. 2013, } \\
\text { Shakoor et al. 2014, Abbas et al. } \\
\text { 20114, Kemal, 2011, Kouser \& } \\
\text { Saba, 2011 and Ray, 2013)" }\end{array}$ \\
\hline & $\begin{array}{l}\text { Earnings Per } \\
\text { Share }\end{array}$ & EPS & $\begin{array}{l}\text { Net Profit after Tax / } \\
\text { No. of Ordinary Share }\end{array}$ & $\begin{array}{l}\text { “ (Abbas et al. 2014, } \\
\text { Kayani et al. 2013, Ray 2013, } \\
\text { Ahmed and Ahmed 2014, Kemal } \\
\text { 2011, Lin et al. 2006, Sinha and } \\
\text { Kaushik, 2010; Muhammad, } \\
\text { 2010 and Shakoor et al. 2014,)” }\end{array}$ \\
\hline & $\begin{array}{l}\text { Return on Capital } \\
\text { Employed }\end{array}$ & $\mathrm{RCE}$ & $\begin{array}{l}\text { Net Profit before Tax / } \\
\text { (Total Assets - Current } \\
\text { Liabilities) }{ }^{*} 100\end{array}$ & $\begin{array}{l}\text { "(Ray 2013, Kumara \& } \\
\text { Satyanarayana, 2013; Ray 2013; } \\
\text { Kemal 2011, Kouser \& Saba } \\
\text { 2011)" }\end{array}$ \\
\hline $\mathrm{O}$ & Debt Ratio & DR & $\begin{array}{l}\text { (Total Liabilities / Total } \\
\text { Assets) }{ }^{*} 100\end{array}$ & $\begin{array}{l}\text { "(Abbas et al. 2014, } \\
\text { IrfanShakoor et al. 2014, Kemal, } \\
\text { 2011, Alam et al. 2011; Ray, 2013 } \\
\text { and Ahmed and Ahmed 2014)" }\end{array}$ \\
\hline 1 & $\begin{array}{l}\text { Interest Coverage } \\
\text { Ratio }\end{array}$ & ICR & $\begin{array}{l}\text { Earnings before interest } \\
\text { \& Taxes / Interest } \\
\text { Expense }\end{array}$ & $\begin{array}{l}\text { "(Ray 2013, Shakoor et } \\
\text { al. 2014, Abbas et al. 2014; Ray } \\
\text { 2013; Ahmed \& Ahmed } 2014 \text { and } \\
\text { Kemal 2011)" }\end{array}$ \\
\hline 2 & Debt to Equity & $\mathrm{DE}$ & $\begin{array}{l}\text { Total Debt / Total } \\
\text { Equity }\end{array}$ & $\begin{array}{l}\text { "(Kumara } \\
\text { Satyanarayana, 2013, Abbas et } \\
\text { al. 2014, Arshad 2012, Kemal } \\
\text { 2011, Kouser \& Saba 2011; } \\
\text { Shakoor et al. 2014)" }\end{array}$ \\
\hline 3 & Capital Ratio & CR & $\begin{array}{l}\text { (Total Shareholders } \\
\text { Equity / Total Assets) * } \\
100\end{array}$ & $\begin{array}{l}\text { "( Ilahi et al,. 2014; } \\
\text { Abbas et al., 2014; Ahmed \& } \\
\text { Ahmed, 2014; Arshad, } 2012 \text { and } \\
\text { Kemal, 2011)" }\end{array}$ \\
\hline
\end{tabular}

\section{Hypothesis}

Mergers \& acquisitions have both a negative and a beneficial impact on an organization's financial performance, according to an assessment of the literature. The purpose of this study is to determine the influence of mergers \& acquisitions on the financial performance of Micro Finance Banks in Pakistan.

The following hypothesis will be used:

H1: The liquidity position has not been significantly affected by the mergers \& acquisitions of microfinance banks in Pakistan.

H2: Profitability has not been significantly affected by mergers \& acquisitions of microfinance banks in Pakistan. 
H3: Solvency has not been significantly affected by mergers \& acquisitions of microfinance banks in Pakistan.

\section{Research Methodology}

Previous studies that were undertaken to evaluate and assess the influence of mergers \& acquisitions on the financial performance of various firms used a variety of techniques and approaches. Shakoor et al. (2014) examine the influence of mergers \& acquisitions on the profitability of Pakistan's banking industry. Examined the effect of mergers \& acquisitions on the financial performance of Pakistan's banking industry using financial ratios and accounting data, as well as a paired T-test for data analysis (Kousar and Saba, 2011). Abbas et al. (2014) conducted a financial analysis of Pakistani banks before and after mergers \& acquisitions. To quantify financial performance, many financial indicators were employed, including liquidity, profitability, efficiency, and leverage, which were quantified using various financial ratios.

This study, based on previous research, employed the liquidity ratio, profitability ratio, and solvency ratio to evaluate the financial performance of chosen microfinance banks before and after mergers \& acquisitions. Following methodology, this research analyzed data using paired T-tests (Kousar \& Saba, 2011).

\subsection{Population}

There are multiple banks are working in Pakistan, including 5 public sector banks, four specialized banks, sixteen private banks, six Islamic banks, four foreign banks, and ten microfinance banks; And the target population of this study are microfinance banks constitute the study's population.

\subsection{Simple Size}

The Competition Commission of Pakistan (CCP) website has information on mergers \& acquisitions that have occurred in Pakistan, with a total of 426 mergers \& acquisitions occurring between 2005 and December 31, 2021. Only three microfinance bank mergers \& acquisitions occurred in Pakistan, and all three microfinance institutions were chosen as a sample to assess financial performance.

\subsection{T- Test}

To determine whether a sample mean or difference in means between two samples is statistically significant when the sample size is small or the population variance is unknown, a common approach is to utilize the T-test. T-tests may be used to determine significance when two samples are connected, and the paired t-test (also known as the difference test) is used to do so. Additional uses include assessing the significance of simple and partial correlation coefficients. The appropriate test statistic, $t$, is generated from the sample data and then compared to its likely value as determined by the t-distribution to determine whether the null hypothesis is accepted or rejected at a defined level of significance for the degrees of freedom involved.

\subsection{T-test on Paired Samples}

The paired t-test is employed in this study to analyse financial performance for pre- and postmergers and acquisition periods. Several other research with comparable goals have previously made use of the approach (Mantravadi \& Reddy, 2008; Saboo \& Gopi, 2009; Pazarskis et al. 2010; Ray, 2013; Prasad \& Mahesh, 2012). This research technique was selected because of the findings' uniformity and comparability (Vanitha \& Selvam, 2007). 


\section{Result and Discussion}

Financial ratios were calculated using financial data from audited financial statements of Tameer Microfinance Bank, U Microfinance Bank, and FINCA Microfinance Bank before and after mergers \& acquisitions. Profitability, liquidity, and solvency ratios were all investigated.

\subsection{Result of Paired Sample T-test}

Use SPSS to calculate a "paired sample t-test" by taking the weighted average of all chosen micro-finance banks in Pakistan based on their total assets and multiplying this weighted average to the result of all ratios.

\subsection{Liquidity Ratios}

A paired sample t-test of liquidity ratios for selected microfinance banks in Pakistan was conducted before and after the time of mergers \& acquisitions.

Table. 2

\begin{tabular}{|l|c|c|c|c|c|c|c|}
\hline \multicolumn{1}{|c|}{ Ratios } & $\begin{array}{c}\text { Pre- } \\
\text { Merger }\end{array}$ & $\begin{array}{c}\text { Post- } \\
\text { Merger }\end{array}$ & $\begin{array}{c}\text { Mean } \\
\text { Different }\end{array}$ & S.D & T & $\begin{array}{c}\text { Sig.(2- } \\
\text { Tailed) }\end{array}$ & S*/NS** \\
\hline Current Ratio & 0.143 & 0.116 & 0.027 & 0.029 & 1.625 & 0.246 & $\begin{array}{c}\text { Not } \\
\text { Significant }\end{array}$ \\
\hline $\begin{array}{l}\text { Investment to } \\
\text { Total Assets }\end{array}$ & 1.680 & 2.112 & 0.432 & 0.963 & -0.778 & 0.518 & $\begin{array}{c}\text { Not } \\
\text { Significant }\end{array}$ \\
\hline $\begin{array}{l}\text { Advances to } \\
\text { Total Assets }\end{array}$ & 14.949 & 18.227 & 3.278 & 2.686 & -2.114 & 0.169 & $\begin{array}{c}\text { Not } \\
\text { Significant }\end{array}$ \\
\hline $\begin{array}{l}\text { Deposit to } \\
\text { Total Assets }\end{array}$ & 17.527 & 20.123 & 2.597 & 4.582 & -.982 & 0.430 & $\begin{array}{c}\text { Not } \\
\text { Significant }\end{array}$ \\
\hline
\end{tabular}

NS**: Not Significant

$S^{*}$ : Significant

Table. 2 shows that after the calculation of paired T-Test, there is a insignificant change in the $\mathrm{CR}$ ratio of all three microfinance banks in the pre and post period of mergers \& acquisitions, i.e., from 0.1430 .029 to 0.1160 .029 , ( $\mathrm{P}>0.05$ ), i.e., 0.246 . There is a statistically insignificant change in the ITA ratio of of three microfinance banks in the pre and post period of mergers \& acquisitions, i.e., from 1.6800 .963 to 2.1120 .963 ( $\mathrm{P}>0.05$ ), i.e., 0.518. There is a insignificant change in the ATA ratio of all selected microfinance banks in the pre and post period of mergers \& acquisitions, i.e., from 14.949 2.686 to 18.227 2.686, ( $>$ > o.05), i.e., 0.169. There is a insignificant change in the DTA ratio of all three microfinance banks in the pre and post period of mergers \& acquisitions, i.e., from 17.5274 .582 to 20.1234 .582 ( $\mathrm{P}>$ o.05), i.e., 0.430. The H1 is not rejected in light of the above data, implying that there is no substantial difference in liquidity ratios between before and after mergers \& acquisitions of chosen microfinance banks in Pakistan.

\subsection{Profitability Ratios}

The results of a Paired Sample t-Test of Profitability Ratios on Selected Microfinance Banks in Pakistan before to and after mergers \& acquisitions. 
Table. 3

\begin{tabular}{|l|c|c|c|c|c|c|c|}
\hline \multicolumn{1}{|c|}{ Ratios } & $\begin{array}{c}\text { Pre- } \\
\text { Merger }\end{array}$ & $\begin{array}{c}\text { Post- } \\
\text { Merger }\end{array}$ & $\begin{array}{c}\text { Mean } \\
\text { Different }\end{array}$ & S.D & T & $\begin{array}{c}\text { Sig.(2- } \\
\text { Tailed) }\end{array}$ & $\mathbf{S * / N S * *}^{* * 2}$ \\
\hline $\begin{array}{l}\text { Return on } \\
\text { Assets }\end{array}$ & -1.298 & 0.980 & 2.278 & 2.617 & -1.507 & 0.271 & $\begin{array}{c}\text { Not } \\
\text { Significant }\end{array}$ \\
\hline $\begin{array}{l}\text { Return on } \\
\text { Equity }\end{array}$ & -5.727 & 4.660 & 10.380 & 10.064 & -1.788 & 0.216 & $\begin{array}{c}\text { Not } \\
\text { Significant }\end{array}$ \\
\hline $\begin{array}{l}\text { Net Profit } \\
\text { Margin }\end{array}$ & -12.597 & 1.299 & -13.890 & 21.890 & -1.099 & 0.386 & $\begin{array}{c}\text { Not } \\
\text { Significant }\end{array}$ \\
\hline $\begin{array}{l}\text { Return on } \\
\text { Capital } \\
\text { Employed }\end{array}$ & -1.493 & -0.203 & -1.289 & 2.154 & -1.037 & 0.409 & $\begin{array}{c}\text { Not } \\
\text { Significant }\end{array}$ \\
\hline $\begin{array}{l}\text { Earnings per } \\
\text { Share }\end{array}$ & -0.367 & 0.296 & 0.663 & 0.770 & -1.492 & 0.274 & $\begin{array}{c}\text { Not } \\
\text { Significant }\end{array}$ \\
\hline
\end{tabular}

$N S^{* *}$ : Not Significant

\section{$S^{*}:$ Significant}

Table 3 shows that after the calculation of paired T-Test, there is a statistically insignificant change in the ROA ratio of all three microfinance banks in the pre and post period of mergers \& acquisitions, i.e., from-1.298 2.617 to 0.9802 .617 , ( $\mathrm{P}>0.05$ ), i.e., 0.271. There is a statistically insignificant change in the ROE ratio of all three microfinance banks in the pre and post period of mergers \& acquisitions, i.e., from-5.727 10.064 to 4.660 10.064, (P > o.05) i.e., 0.216.

There is a insignificant change in the NPM ratio of all three microfinance banks in the pre and post period of mergers \& acquisitions, i.e., from-12.597 21.890 to 1.29921 .890 (P > 0.05), i.e., o.386. There is a insignificant change in the ROCE ratio of all three microfinance banks in the pre and post period of mergers \& acquisitions, i.e., from-1.493 2.154 to-0.203 2.154 (P > 0.05), i.e., 0.409. There is a insignificant change in the EPS ratio of all three microfinance banks in the pre and post period of mergers \& acquisitions, i.e., from -0.367 0.770 to 0.2960 .770 ( $\mathrm{P}>0.05$ ), i.e., 0.274. The H2 is not rejected in light of the following data, implying that there is no substantial difference in profitability ratios between before and after mergers \& acquisitions of chosen microfinance banks in Pakistan.

\subsection{Solvency Ratios}

The results of a Paired Sample t-Test on Profitability Ratios for Selected Microfinance Banks in Pakistan before and after mergers \& acquisitions. 
Table. 4

\begin{tabular}{|l|c|c|c|c|c|c|c|}
\hline \multicolumn{1}{|c|}{ Ratios } & $\begin{array}{c}\text { Pre- } \\
\text { Merger }\end{array}$ & $\begin{array}{c}\text { Post- } \\
\text { Merger }\end{array}$ & $\begin{array}{c}\text { Mean } \\
\text { Different }\end{array}$ & S.D & $\mathbf{t}$ & $\begin{array}{c}\text { Sig.(2- } \\
\text { Tailed) }\end{array}$ & $\mathbf{S}^{*} / \mathbf{N S}_{* *}$ \\
\hline Debt Ratio & 20.443 & 24.064 & 3.621 & 4.469 & -2.403 & 0.296 & $\begin{array}{c}\text { Not } \\
\text { Significant }\end{array}$ \\
\hline $\begin{array}{l}\text { Times Interest } \\
\text { Earned Ratio }\end{array}$ & 1.506 & 2.205 & 0.699 & 0.974 & -1.244 & 0.340 & $\begin{array}{c}\text { Not } \\
\text { Significant }\end{array}$ \\
\hline $\begin{array}{l}\text { Debt to Equity } \\
\text { Ratio }\end{array}$ & 0.910 & 1.062 & 0.151 & 0.498 & -0.527 & 0.651 & $\begin{array}{c}\text { Not } \\
\text { Significant }\end{array}$ \\
\hline Capital Ratio & 12.889 & 9.269 & 3.619 & 4.467 & 1.404 & 0.296 & $\begin{array}{c}\text { Not } \\
\text { Significant }\end{array}$ \\
\hline
\end{tabular}

$N S^{* *}$ : Not Significant

$S^{*}$ : Significant

Table. 4 shows that after the calculation of paired T-Test, there is a insignificant change in the DR ratio of all three microfinance banks in the pre and post period of mergers \& acquisitions, i.e., from 20.4434 .469 to 24.0644 .469 , ( $\mathrm{P}>$ o.05), i.e., o.296. There is a statistically insignificant change in the IC ratio of all three microfinance banks in the pre and post period of mergers \& acquisitions, i.e., from 1.5060 .974 to 2.2050 .974 ( $\mathrm{P}>$ o.05), i.e., 0.340. There is a statistically insignificant change in the D/E ratio of all three microfinance banks in the pre and post period of mergers \& acquisitions, i.e., from 0.9100 .498 to 1.0620 .498 ( $\mathrm{P}>$ o.05), i.e., o.651. There is a insignificant change in the CR ratio of all three microfinance banks in the pre and post period of mergers \& acquisitions, i.e., from 12.8894 .467 to 9.2694 .467 ( $\mathrm{P}>$ o.05), i.e., o.296. The null hypothesis is not rejected in light of the given data, implying that there is no significant difference in terms of solvency ratios between before and after mergers \& acquisitions of chosen microfinance banks in Pakistan.

\section{Conclusion}

General banking and microfinance banking are both affected by mergers \& acquisitions (mergers \& acquisitions) in addition to other reasons. According to Shakoor et al., (2014) mergers \& acquisitions in Pakistan's banking business began in 2002. But in Pakistan's microfinance banking sector, mergers \& acquisitions are a relatively new phenomenon. In 2005, Telenor Pakistan bought a 51\% stake in Tameer Bank as the first step in the deal. All countries must have microfinance banks in order to prosper. However, little attention has been paid to the impact of microfinance bank mergers \& acquisitions in Pakistan, particularly. In order to evaluate a company's financial performance, financial metrics such as liquidity, profitability, and solvency are used.

The CR, ITA, DTA, and ATA ratios are calculated as part of the liquidity ratio. The CR of Tameer microfinance banks and Finca microfinance banks decreased after mergers \& acquisitions, indicating that these banks have less liquidity and are less able to meet their short-term obligations. The CR of microfinance banks improved in the post-mergers and acquisition period, demonstrating its ability to meet its short-term obligations. After mergers \& acquisitions, the ITA ratio of all selected microfinance banks drops, but this is not statistically significant. The hypothesis 1 is not rejected in light of the outcome. 
A profitability ratio is critical for determining a company's financial health. ROA, ROE, NPM, ROCE, and EPS are among the profitability ratios. The ROA of TMFB and Finca microfinance banks improves after mergers and acquisition, whereas the ROA of U-microfinance banks drops in the post-mergers and acquisition era, indicating that TMFB and Finca microfinance banks use their assets more efficiently after mergers and acquisition than UMFB. The ROA of all chosen microfinance banks improves after mergers \& acquisitions, but the difference is statistically negligible. The ROE of TMFB and Finca microfinance banks improves after mergers and acquisition, whereas the ROE of Umicrofinance banks declines, indicating that TMFB and Finca microfinance banks pay higher returns to their owners after mergers and acquisition than UMFB. After mergers \& acquisitions, the ROE of all selected microfinance banks drops, although it is not statistically significant. The net profit margin of Tameer microfinance banks and Finca microfinance banks improves after mergers and acquisition, whereas the NPM of U-microfinance banks declines, indicating that Tameer microfinance banks and Finca microfinance banks are more effective at translating sales into actual profit after mergers and acquisition than UFMB. After mergers and acquisition, the NPM of all selected microfinance banks shows a negative influence, but it is not statistically significant. Another profitability ratio is ROCE, which shows that after mergers \& acquisitions, the ROCE of Tameer microfinance banks and Finca microfinance banks increases, indicating that returns are higher than the cost of capital, whereas the ROCE of U-microfinance banks decreases, indicating that returns are lower than the cost of capital in the post mergers and acquisition period. After mergers \& acquisitions, the ROCE of all selected microfinance banks reveals a negative influence, but this is not statistically significant. In the post-mergers and acquisition period, the EPS of Tameer microfinance banks and Finca microfinance banks improved, but the EPS of UFMB decreased. After mergers \& acquisitions, the EPS of all selected microfinance banks improves, although it is not statistically significant. The hypothesis 2 is not rejected in light of the above-mentioned outcome.

All of the above are solvency ratios: DR, IC, D/E, and CR. The DRs of Tameer microfinance banks and U-microfinance banks increase, indicating that the banks' debt has increased and their ability to pay long-term obligations has decreased, but the DR of Finca microfinance banks improves, indicating that the banks' debt has decreased and their ability to pay long-term obligations has increased as a result of the mergers \& acquisitions. The DR of all chosen microfinance banks increased after the mergers \& acquisitions, but this increase is not statistically significant. All of the chosen banks' ICs are positive, implying that these institutions will be better positioned to meet their interest payments following the merger and acquisition. Although the difference was not statistically significant, the ICs of all microfinance banks improved after mergers \& acquisitions. The D/E of Tameer microfinance banks and U-microfinance banks after mergers \& acquisitions shows that banks are able to collect more money but are having difficulty repaying it, while the $\mathrm{D} / \mathrm{E}$ of Finca microfinance banks improves following mergers \& acquisitions, indicating that the bank is able to pay both interest and principal. The D/E of all chosen microfinance banks rises after mergers \& acquisitions, although not statistically significantly. While the CR of Tameer microfinance banks and U-microfinance banks declines after mergers \& acquisitions, the CR of Finca microfinance banks increases, implying that Tameer microfinance banks and U-microfinance banks may have a greater percentage of fixed assets in relation to loans and equity in the post-mergers and acquisition period than Finca microfinance banks. Following mergers \& acquisitions, the CRs of all chosen microfinance banks show a negative effect, although this effect is not statistically significant. In light of the aforementioned conclusion, the hypothesis 3 is not rejected.

In the end, it is concluded that the null hypothesis is accepted, which shows that there is no significant impact of mergers \& acquisitions in terms of liquidity, profitability, and solvency positions of 
selected microfinance banks in Pakistan, which is similar to the finding of Abbas et al. (2014), which concluded that overall, the activity of mergers \& acquisitions did not perform well in the banking sector of Pakistan. Mishra and Chandra (2010) investigated whether mergers in the Indian pharmaceutical business resulted in improved company performance in the Indian context. According to the findings, mergers did not improve the firm's performance. To verify the result, unstructured interviews with the senior officers of selected microfinance banks were conducted and different factors, such as

- Withdrawal of investment at the time of mergers and acquisition

- Unawareness among people about microfinance banks

- Banks' logos and names should be changed.

- The organization culture of these banks

From the interviews of the experts in the microfinance banking sector, it was revealed that the above mentioned are the factors due to which no significant impact has become visible on mergers \& acquisitions of microfinance banks in Pakistan. The same factors were also identified by (Abbas et al. 2014; Feyitimi, 2014).

\section{Future research Directions}

In the future, research on cross-border mergers \& acquisitions might be conducted in all other industries, using other methods for measuring financial factors. This is due to the fact that each company has distinct characteristics and contextual realities that may have an impact on mergers and acquisition. The study's analysis is entirely based on ratio analysis; however, future research may be investigate the mergers and acquisition in a different of ways. Additionally, you may use the DEA, event window, and OLS approaches. Primary research on the same subject may be conducted in Pakistan. Merger development is laden with peril. A study should be done to ascertain the barriers to merger formation and why many firms have refrained from forming mergers despite the advantages.

\section{Reference}

Agarwal K. P. and Sinha K. S. (2010), "Financial Performance of Microfinance Institutions of India", Delhi Business Review, Vol. 11, No. 2.

Abbas Q., Hunjra I. A., Saeed R., Hassan U. E. and Ijaz S. M. (2014), "Analysis of Pre and Post Merger and Acquisition Financial Performance of Bank in Pakistan", Information Management and Business Review, Vol. 6, No.4, pp. 177-190.

Aggarwal, P., \& Garg, S. (2019). Impact of mergers \& acquisitions on accounting-based performance of acquiring firms in India. Global Business Review, 0972150919852009.

Ahmed M. and Ahmed Z. D. (2014), "mergers \& acquisitions: Effect on Financial Performance of Banking Institutions of Pakistan”, ISSN 2090-4304, J. Basic. Appl. Sci. Res., 4(4)249-259.

Ashfaq K. (2014), "Investigating the Impact of Merger \& Acquisition on Post Merger Financial Performance (Relative \& Absolute) of Companies (Evidence from Non-Financial Sector of Pakistan)", Research Journal of Finance and Accounting, ISSN 2222-1697 (Paper) ISSN 22222847 (Online).Vol.5, No.13.

Abdul A. and Ojenike O.J. (2014), "Impact of mergers \& acquisitions on Performance of Companies in Oil and Gas Industry”, European Journal of Business and Management, ISSN 2222-1905 (Paper) ISSN 2222-2839 (Online), Vol.6, No.32.

Bi Z. P. and Pandey D. L. S. D. (2011), "Comparison of Performance of Microfinance Institutions with Commercial Banks in India”, Australian Journal of Business and Management Research, Vol. 1, No. 6 (110-120).

Chellasamy P. and Ponsabariraj N. (2012), "Performance Evaluation of mergers \& acquisitions of 
Scheduled Commercial Banks in India".

Dilshad N. M. (2013). "Profitability Analysis of mergers \& acquisitions: An Event Study Approach", Business and Economic Research, ISSN 2162-486o.Vol. 3, No. 1.

Fatima T. and Shehzad A. (2014), "An Analysis of Impact of Merger and Acquisition of Financial Performance of Banks: A Case of Pakistan”, Journal of Poverty, Investment and Development, Vol. 5 .

Ireri K. J. (2011), "Effects of mergers \& acquisitions on Financial Performance of Oil Companies in Kenya".

Gupta, I., Raman, T. V., \& Tripathy, N. (2021). Impact of Merger and Acquisition on Financial Performance: Evidence from Construction and Real Estate Industry of India. FIIB Business Review, 23197145211053400.

Kumari P. (2014), “mergers \& acquisitions in Indian Banking Sector- A Strategic Approach”, Global Journal of Finance and Management, ISSN o975-6477 Volume 6, Number 3 (2014), pp. 217-222.

Kipesha F. E. (2013), "Performance of Microfinance Institutions in Tanzania: Integrating Financial and Non Financial Metrics”, European Journal of Business and Management, ISSN 2222-1905 (Paper), ISSN 2222-2839 (Online) Vol. 5, No.4.

Kayani J. A., Javed B., Majeed A. and Shaukat A. (2013), "Impact of Merger and Acquisition on Operating Performance and shareholder Wealth in Pakistan Banking Sector”, Interdisciplinary Journal of Contemporary Research Business, Vol. 5, No. 6.

Kouser R. and Saba I. (2011), "Effects of Business Combination on Financial Performance: Evidence from Pakistan's Banking Sector”, Australian Journal of Business and Management Research, Vol.1 No.8 [54-64].

Kanahalli M. B. and Jayaram S. (2014), "Effect of mergers \& acquisitions on Financial Performance: A Study of Select TATA Group Companies in India”, International Research Journal of Management and Commerce, ISSN: (2348-9766), Volume-1, Issue-8.

Lole M. T. (2011), “The Effects of mergers \& acquisitions of Financial Performance of Insurance Companies in Kenya: A Case Study of APA Insurance Limited".

Mishra P. and Chandra T. (2010), "Mergers, Acquisitions and Firms' Performance: Experience of Indian Pharmaceutical Industry”, Eurasian Journal of Business and Economics, 3 (5), 111-126.

Malik F. M., Anuar A. M., Khan S. Khan F. (2014), "mergers \& acquisitions: A Conceptual Review", International Journal of Accounting and Financial Reporting, ISSN 2162-3082, Vol. 4, No. 2.

Narwal P. K., Pathneja S. and Yadav K. M. (2015), "Performance Analysis of Banks and Microfinance Institutions in India”. Int. J. Mang. Bus. Res., 5 (1), 9-18.

Ongore O.V and Kusa B.G (2013), "Determinants of Financial Performance of Commercial Banks in Kenya”, International Journal of Economics and Financial Issues, Vol. 3, 1, 2013, pp. 237-252.

Poposki K. (2007), "Merger Activity in the Insurance Industry", Economics and Organization, Vol. 4, No 2, 2007, pp. $161-171$.

Shakoor I, M., Nawaz M., Asab Z. M. and Khan A. W. (2014), "Do mergers \& acquisitions Vacillate the Banks Performance?”, Research Journal of Finance and Accounting, ISSN 2222-1697 (Paper) ISSN 2222-2847 (Online), Vol. 5, No. 6.

Shah Q.S. and Jan R. (2014), “Analysis of Financial Performance of Private Banks in Pakistan”. Social and Behavioral Science 109 (2014) 1021-1025.

Tarawneh M. (2006), "A Comparison of Financial Performance in the Banking Sector: Some Evidence from Omani Commercial Banks”, International Research Journal of Finance and Economics, ISSN 1450-2887 Issue 3. 